\title{
Avirulence of 27 Bacteria That Are Budding, Prosthecate, or Both
}

\author{
O. FAMUREWA, $\dagger$ H. G. SONNTAG, $\dagger$ AND P. HIRSCH* \\ Institut für Allgemeine Mikrobiologie, Institut für Hygiene und medizinische Mikrobiologie, Universität Kiel, \\ Kiel, Federal Republic of Germany
}

\begin{abstract}
We tested the possible pathogenicity of 27 bacteria that are budding or prosthecate or both in mice and guinea pigs. The strains tested belong to the following taxa: Hyphomicrobium (12 strains), "Hyphomonas"' (4 strains), Pedomicrobium (2 strains), Rhodomicrobium (2 strains), Prosthecomicrobium (1 strain), "Stella"' (1 strain), Blastobacter (2 strains), Planctomyces (1 strain), and Pasteuria (1 strain); 1 strain was unnamed. Mice injected intraveneously with a $0.5-\mathrm{ml}$ suspension containing up to $10^{9}$ colony-forming units per ml survived for 7 days without macroscopic changes, abscesses, or lesions. Four Hyphomicrobium strains, one "Hyphomonas" strain, and the unnamed strain caused slight spleen enlargement and in some cases a mottled kidney appearance; however, the organs were histologically normal, and the changes observed were considered to be signs of host reaction rather than pathological changes. Subcutaneous injections also did not result in disease. Two Rhodomicrobium strains could be reisolated from mice after 21 days; none of the other strains could be recovered after 7 days. Lethal endotoxic activity was not detected with any of the strains when cell sonic extracts were injected intraveneously. All strains caused antibody formation, and agglutination dilution titers ranged from $1: 2$ to $1: 64$. Serological cross-reactions with six strains indicated the presence of distinct taxonomic groups. Hyphomicrobia from soil cross-reacted with each other but not with hyphomicrobia from aquatic sources. Immunosuppressive pretreatment with Natulan did not render the mice more susceptible. Other possible indicators of pathogenicity (i.e., mannitol utilization and $\beta$-hemolysis) were not observed in the 27 strains. We concluded that the 27 bacteria tested are nonpathogenic for mice or guinea pigs under the conditions used.
\end{abstract}

Recently, an increasing number of morphologically unusual bacteria have been isolated in pure culture. Among these, gram-negative bacteria that are budding or prosthecate or both have attracted special attention because of their unique morphologies, life cycles, and physiologies $(13-18,37)$. The sources of isolation have varied and have included soil $(14,39)$, freshwater $(17,37)$, brackish water $(17,18)$, seawater $(1$, 22), and even humans (31). Many of these bacteria comprise new species or even genera, and so far only a few have been studied in enough detail to be included in standard determinative bacteriology texts (4).

As physiological properties and differentiation are investigated, high cell yields are processed. However, little, if anything, is known about the pathogenicities of these unusual bacteria. Since most of these bacteria have not been obtained from human or animal hosts, the notion that

\footnotetext{
† Present address: Hygiene Institut, Universität Heidelberg, 6900 Heidelberg, Federal Republic of Germany.
}

these organisms are probably not pathogenic prevails. However, Hurlbert et al. (19), Weckesser et al. (41), and Katz et al. (20) have demonstrated that there are potentially pathogenic cell surface components in phototrophic bacteria. On the other hand, the budding and hyphal gram-negative organism "Hyphomonas polymorpha," which was obtained from infectious sinusitis, reportedly is not pathogenic (31).

The aim of this study was to investigate the pathogenicities of 27 new morphologically and physiologically unusual bacteria. Laboratory animals (mice and guinea pigs) were challenged as potential hosts by administering high cell numbers and using different modes of infection. Our results indicate that the strains were not pathogenic for the hosts tested, although host reactions to the bacterial antigens were observed.

\section{MATERIALS AND METHODS}

Microorganisms. A total of 27 strains of morphologically unusual bacteria were investigated. According to present taxonomy and nomenclature, these strains 
belong to the genera Hyphomicrobium (12 strains), "Hyphomonas", (4 strains), Pedomicrobium (2 strains), Rhodomicrobium (2 strains), Prosthecomicrobium (1 strain), "Stella" (1 strain), Blastobacter (2 strains), Planctomyces (1 strain), and Pasteuria (1 strain). One strain (IFAM 1128) cannot be affiliated yet with any presently known genus. The names, culture media used, sources of isolation, and donors of these organisms are listed in Table 1.

The pathogenic strains Staphylococcus aureus ATCC 6538 and Escherichia coli ATCC 11229 were used as positive controls. All cultures were maintained on agar slants stored at $6^{\circ} \mathrm{C}$ in the dark.

Animals. White albino mice of the specific-pathogen-free strain BALB/c(H-2 $\left.{ }^{\mathrm{d}}\right)$ and female brown mice of the specific-pathogen-free strain $\mathrm{C} 3 \mathrm{H}\left(\mathrm{H}-2^{\mathrm{k}}\right)$ were used. These animals were kept in groups of up to 10 on sterilized sawdust in disinfected Macrolon cages (type III; PAG, Essen, Federal Republic of Germany) at about $23^{\circ} \mathrm{C}$. They were fed with type 1314 Altromin pellets (Altromin, Lage, Federal Republic of Germany) and water ad libitum.

Guinea pigs (Cavia sp.) were kept individually in type III Macrolon cages at $22^{\circ} \mathrm{C}$ and fed type 3012 Altromin and water ad libitum. The mice weighed between 20 and $40 \mathrm{~g}$ and were between 6 and 20 weeks old at the start of the experiment. The guinea pigs weighed 400 to $550 \mathrm{~g}$ and were about 16 weeks old. All animals used were bred and supplied by the Institut fur Hygiene und medizinische Mikrobiologie, Universität

TABLE 1. Bacterial test strains, origins, culture media, and sources

\begin{tabular}{|c|c|c|c|c|}
\hline Strain(s) & Origin and enrichment & Medium $^{a}$ & $\begin{array}{l}\text { Maximum } \\
\text { growth } \\
\text { temp }\left({ }^{\circ} \mathrm{C}\right)\end{array}$ & Reference(s) \\
\hline \multicolumn{5}{|l|}{ Hyphomicrobium spp. } \\
\hline IFAM B-522, IFAM H-526 & Lawn soil; mineral salts & 337-M & $>37$ & 15 \\
\hline $\begin{array}{l}\text { IFAM NQ-521 gr, IFAM } \\
\text { MEV-533gr }\end{array}$ & River water; mineral salts & $337-\mathrm{M}$ & $>37$ & 25 \\
\hline IFAM I-551, IFAM CO-582 & $\begin{array}{l}\text { Soil; mineral salts, } \mathrm{CO} \text { and } \\
\quad \mathrm{O}_{2}\end{array}$ & $337-\mathrm{M}$ & $>37$ & 24 \\
\hline IFAM ZV-580, IFAM ZV-622 & $\begin{array}{l}\text { Peat soil; mineral salts, } \\
\text { methanol }\end{array}$ & $337-\mathrm{M}$ & $>37$ & 42 \\
\hline $\begin{array}{l}\text { IFAM MC-748, IFAM MC- } \\
750\end{array}$ & $\begin{array}{l}\text { Soil; mineral salts, methanol } \\
\text { or methylamine }\end{array}$ & $337-\mathrm{M}$ & $>30$ & 24 \\
\hline IFAM Wi-926 & Pond water; mineral salts & $337-\mathrm{M}$ & 38 & Wieczorek $^{b}$ \\
\hline IFAM KB-677 & Sewage; mineral salts & $337-\mathrm{M}$ & $>30$ & 21 \\
\hline $\begin{array}{l}\text { Hyphomicrobium neptunium } \\
\text { IFAM LE-670 }\end{array}$ & $\begin{array}{l}\text { Seawater; Casitone, yeast } \\
\text { extract, Tris buffer, ASW }\end{array}$ & 383 & 40 & 22 \\
\hline $\begin{array}{l}\text { "Hyphomonas polymorpha" } \\
\text { IFAM PR-727, IFAM PS-728 }\end{array}$ & $\begin{array}{l}\text { Nasal sinus infection; blood } \\
\text { gelatin, } 37^{\circ} \mathrm{C}\end{array}$ & Nutrient agar & $>37$ & 31 \\
\hline $\begin{array}{l}\text { Hyphomonas-like strain IFAM } \\
1325\end{array}$ & $\begin{array}{l}\text { Baltic Sea brackish water; } \\
\text { sample stored in labora- } \\
\text { tory }\end{array}$ & $\begin{array}{l}\text { PYGV }+25 \% \\
\text { ASW }\end{array}$ & $>30$ & 17 \\
\hline $\begin{array}{l}\text { Pedomicrobium-like strains } \\
\text { IFAM } 868, \text { IFAM } 869\end{array}$ & Puddle water; mineral salts & PYGV & $>30$ & 11; Babinchak \\
\hline Unnamed strain IFAM 1128 & Rock puddle; yeast extract & $\begin{array}{l}\text { PYGV + } \\
0.1 \% \text { yeast } \\
\text { extract }\end{array}$ & 36 & 9 \\
\hline $\begin{array}{l}\text { Rhodomicrobium vannielii } \\
\text { IFAM 1093, IFAM } 1178^{\mathrm{T}} \\
\left(=\text { ATCC } 17100^{\mathrm{T}}\right)\end{array}$ & $\begin{array}{l}\text { Pond water; ethanol, light, } \\
\text { anaerobic }\end{array}$ & 391 & 54 & 8; Roggentin ${ }^{f}$ \\
\hline $\begin{array}{l}\text { Prosthecomicrobium sp. strain } \\
\text { IFAM } 1316\end{array}$ & $\begin{array}{c}\text { Baltic Sea brackish water; } \\
0.0025 \% \text { Bacto-Peptone }\end{array}$ & 387 & $37-39$ & 17 \\
\hline "Stella" sp. strain IFAM 1312 & $\begin{array}{l}\text { Baltic Sea brackish water; } \\
0.05 \% \text { casein hydrolysate }\end{array}$ & $\begin{array}{l}\text { PYGV + } 25 \% \\
\text { ASW }\end{array}$ & $38.5-41$ & 17 \\
\hline $\begin{array}{l}\text { Blastobacter spp. strains IFAM } \\
\text { 1003, IFAM } 1005\end{array}$ & Lake water; PYGV medium & PYGV & 41,46 & Müller ${ }^{g}$ \\
\hline $\begin{array}{l}\text { "Planctomyces limnophilus" } \\
\text { IFAM } 1007\end{array}$ & Lake water; PYGV medium & PYGV & 39 & Müller ${ }^{g}$ \\
\hline Pasteuria ramosa IFAM 1009 & Lake water; PYGV medium & PYGV & 30 & Müller ${ }^{g}$ \\
\hline
\end{tabular}

${ }^{a}$ For an explanation of the media, see the text.

${ }^{b}$ L. Wieczorek, Ph.D. thesis, Universität Kiel, Kiel, Federal Republic of Germany, 1979.

c According to Moore and Hirsch $(4,27)$, this strain is a strain of "Hyphomonas."

${ }^{d}$ Tris, Tris(hydroxymethyl)aminomethane; ASW, artificial seawater.

e W. Babinchak, personal communication.

${ }^{f}$ P. Roggentin, Ph.D. thesis, Universität Kiel, Kiel, Federal Republic of Germany, 1980.

${ }^{g}$ M. Müller, Ph.D. thesis, Universität Kiel, Kiel, Federal Republic of Germany, 1978. 
Kiel, Kiel, Federal Republic of Germany.

Culture media. The following media were used for cultivation of Hyphomicrobium spp.: medium 337-M was prepared by the method of Hirsch and Conti (15) and was supplemented with $3.38 \mathrm{~g}$ of methylamine hydrochloride per liter as the $\mathrm{C}$ source and an additional $\mathrm{N}$ source and only $3 \mathrm{ml}$ of trace element solution; Hyphomicrobium neptunium was grown on seawater medium (22).

Medium PYGV for oligotrophs was prepared by the method of Staley (37), and vitamins were added as described by Van Ert and Staley (39). Artificial seawater, which was added to medium PYGV in some cases, was prepared by the method of Lyman and Fleming (23). Medium 391 has been described previously by Pfennig (29) and contained the trace element solution of Pfennig and Lippert (30), as well as $0.5 \mathrm{~g}$ of $\mathrm{NaHCO}_{3}$ per liter. Medium 387 (J. T. Staley, personal communication) contained $1.0 \mathrm{~g}$ of yeast extract (Difco Laboratories, Detroit, Mich.), $20 \mathrm{ml}$ of Hutner basal salts, $1.0 \mathrm{~g}$ of glucose, and $1,000 \mathrm{ml}$ of distilled water (pH 7.2 after autoclaving).

The $0.1 \%$ yeast extract medium (Difco) used for strain IFAM 1128 (F-1) has been described previously (9). Nutrient broth (Difco) and nutrient agar (Difco) were used for the "Hyphomonas polymorpha" strains; when they were used for Staphylococcus aureus, these media were supplemented with $5 \%$ (vol/ vol) sheep blood. Escherichia coli was grown on China blue-lactose medium (E. Merck AG, Darmstadt, Federal Republic of Germany). To test for mannitol decomposition, we used mannitol- $\mathrm{NaCl}$ agar (Oxoid Ltd., London, England). Hemolysis was tested on nutrient agar containing $5 \%$ (vol/vol) sheep blood. All other solid media were prepared with $1.5 \%$ Bacto-agar (Difco).

Culture conditions. Actively growing cultures were obtained by subculturing agar slants onto $50-\mathrm{ml}$ portions of medium in $125-\mathrm{ml}$ Erlenmeyer flasks, which were then plugged loosely with cotton or ready-made plugs. After visible growth occurred, this procedure was repeated by using a 2 to $5 \%$ inoculum from the growing suspension.

The growth of these active cultures was followed by determining the optical density at $650 \mathrm{~nm}$ with a model 101 spectrophotometer (Hitachi, Tokyo, Japan) and simultaneously determining viable counts in a homogenized suspension. To do this, the cells were harvested by centrifugation and washed twice in sterile phosphate-buffered saline (PBS) ( $\mathrm{pH} 7.2$ ) containing (per liter) $9.78 \mathrm{~g}$ of $\mathrm{Na}_{2} \mathrm{HPO}_{4} \cdot 2 \mathrm{H}_{2} \mathrm{O}, 2.45 \mathrm{~g}$ of $\mathrm{KH}_{2} \mathrm{PO}_{4}$, and $4.5 \mathrm{~g}$ of $\mathrm{NaCl}$. The washed suspensions were then placed in 100-ml screw-capped bottles containing about $20 \mathrm{~g}$ of sterile glass beads (diameter, $3 \mathrm{~mm}$ ). Suspensions were homogenized by shaking for 1 to 3 min. Portions $(1.0 \mathrm{ml})$ of serial dilutions in the buffer described above were spread onto four parallel plates containing the appropriate medium. For the Rhodomicrobium strains, agar shake cultures were prepared instead. Colonies were counted after 2 to 21 days, depending on the strain.

Most cultures were aerated at $30^{\circ} \mathrm{C}$ in the dark. Rhodomicrobium vannielii strains IFAM 1093 and IFAM $1178^{\mathrm{T}}$ (type strain) were grown anaerobically in tightly sealed screw-capped bottles at $23^{\circ} \mathrm{C}$ and 1,500 lx.

Microscopy and photography. All cultures were ex- amined directly with a phase-contrast Photomicroscope II instrument (Zeiss, Oberkochen, Federal Republic of Germany). Agar-coated slides were used for this (17).

Animal assays for pathogenicity. Culture suspensions for the animal assays were grown as described above in $125-\mathrm{ml}$ flasks previously washed with chromosulfuric acid and rinsed with sterile, particle-free, doubledistilled water. Active cells in mid-log phase were injected into animals with nontoxic, pyrogen-free insulin syringes and needles. The mice were sedated with ethyl ether (Aether zur Narkose; Hoechst, Frankfurt, Federal Republic of Germany), and the guinea pigs were injected in a stretched position without sedation.

Generally, each mouse received intraveneously in the tail $0.5 \mathrm{ml}$ of a bacterial suspension containing $10^{3}$, $10^{6}$, or $10^{9}$ colony-forming units (CFU) per ml. For the study of local infectivity, subcutaneous injections were made in the right groin with $0.2 \mathrm{ml}$ of a bacterial suspension containing $10^{9} \mathrm{CFU} / \mathrm{ml}$. Two animals were used per strain. The mice were examined daily for swelling of lymph nodes. Evaluation and dissection of the mice followed after 7 days.

The local infectivity of anaerobic bacteria was studied by injecting $0.1 \mathrm{ml}$ of a suspension $\left(10^{9} \mathrm{CFU} / \mathrm{ml}\right)$ of each Rhodomicrobium strain into a skin fold artificially made just behind the pivot joint in the back. This fold was made with a Michel clamp ( 7.5 by $1.75 \mathrm{~mm}$; Aesculap, Tuttlingen, Federal Republic of Germany). The possible effects of the bacteria that caused organ changes in mice were also studied with guinea pigs injected intraperitoneally with $1-\mathrm{ml}$ portions of washed suspensions $\left(10^{9} \mathrm{CFU} / \mathrm{ml}\right)$. In each experiment another guinea pig was injected with $1 \mathrm{ml}$ of sterile PBS alone.

As positive controls, mice were injected with suspensions containing $5 \times 10^{7} \mathrm{CFU}$ of 18 -h cultures of pathogenic Staphylococcus aureus ATCC 6538 or Escherichia coli ATCC 11229 per ml. Additional control animals were injected with sterile PBS alone. All animals were examined several times daily for lethality, external infection symptoms, and any local changes or swellings for up to 21 days. Then the animals were sacrificed, dissected, and examined for possible internal changes. The organs (kidneys, livers, and spleens) were prepared aseptically for recultivation studies; they were rinsed and homogenized in sterile PBS, and $0.1-\mathrm{ml}$ portions of the suspensions were inoculated onto suitable solid and liquid growth media. Organ suspensions of animals treated with rhodomicrobia were cultivated anaerobically.

Normalization of organs was also investigated. For this, strains which had previously caused spleen enlargement were reinoculated into six mice each, followed by weekly sacrifice of one mouse per strain from week 3 to week 8 . These strains (namely, IFAM NQ-521gr, IFAM MEV-533gr, IFAM I-551, IFAM KB-677, and IFAM 1128) were also tested for toxicity. They were sonicated aseptically for $3 \mathrm{~min}$ in an ice bath (model W185F; Ultrasonics, Plainview, N.Y.), and $0.5 \mathrm{ml}$ of each sonicated cell suspension was injected intraveneously into a mouse (i.e., $5 \times 10^{8}$ $\mathrm{CFU} / \mathrm{ml}$ ). To determine the degree of disruption, 0.1 $\mathrm{ml}$ of each sonic extract was plated onto a suitable agar medium and cultivated.

Infectivity after immunosuppressive treatment. Strain $\mathrm{C} 3 \mathrm{H}\left(\mathrm{H}-2^{\mathrm{k}}\right)$ mice were pretreated with the im- 
munosuppressive drug Natulan [1-methyl-2-p-(isopropylcarbamoyl)benzylhydrazine hydrochloride; lot 0803001; LaRoche, Basel, Switzerland]. The doses used intravenously (and suggested by D. Ulrich, Universität Kiel, Federal Republic of Germany) were 0.5 $\mathrm{ml}$ of $1.39 \%$ solution per $\mathrm{kg}$ of mouse [i.e., $60 \%$ of a $50 \%$ lethal dose for mouse strain BALB/c(H-2 $\left.\left.{ }^{\mathrm{d}}\right)\right]$. After 4 days the mice were infected with $0.5-\mathrm{ml}$ portions of suspensions $\left(10^{9} \mathrm{CFU} / \mathrm{ml}\right)$ of those strains which had caused changes of organs in prior experiments. Control animals, which were also pretreated with Natulan, were infected with $5 \times 10^{7} \mathrm{CFU}$ of Staphylococcus aureus or Escherichia coli per ml, as described above. Additional control animals were injected after Natulan treatment with sterile PBS alone.

Serological examinations (agglutination tests). Antibody determinations with the test strains were carried out from 7 to 21 days after inoculation. Blood from the cardiac area was kept at $22^{\circ} \mathrm{C}$ for $2 \mathrm{~h}$ and then at $4^{\circ} \mathrm{C}$ for $14 \mathrm{~h}$. Serum was obtained by centrifuging the preparation twice at $5,000 \times g$ for $5 \mathrm{~min}$ and then stored at $-20^{\circ} \mathrm{C}$ until it was used. The yield of serum was about $50 \%$ of the blood volume collected. For qualitative antibody demonstrations we used the rocked slide method; $25 \mu$ l of serum was mixed with 25 $\mu l$ of a cell suspension on precleaned, particle-free, glass slides, and the results were read after 3 to $5 \mathrm{~min}$. Quantitative determinations were carried out with serial dilutions of sera in PBA by using microtiter plates (34) and young, homogenized, washed cell suspensions. Results were read after $14 \mathrm{~h}$ of incubation at $37^{\circ} \mathrm{C}$ by using a stereomicroscope at $\times 40$ magnification. For cross-reaction experiments, equal volumes of an antiserum and a bacterial suspension $\left(10^{9}\right.$ $\mathrm{CFU} / \mathrm{ml}$ ) were mixed in microtiter plates and then treated as described above.

Histological studies. Immediately after dissection, organs were removed and fixed in $10 \%$ Formalin for 24 to $48 \mathrm{~h}$ at room temperature; this was followed by dehydration and paraffin embedding, using conventional techniques. Sections $(5 \mu \mathrm{m})$ were cut with a microtome (model 1130; Jung AG, Heidelberg, Federal Republic of Germany) and were stained with periodic acid-Schiff reagent and hematoxylin or with hematoxylin and eosin.

The conventional Pappenheim staining procedure was used in part to demonstrate the possible presence of bacteria.

\section{RESULTS}

Pathogenicity. In an initial experiment, groups of three mice were injected intravenously in the tail with 1 of the 27 strains, using $0.5 \mathrm{ml}$ of a washed cell suspension containing $10^{3}, 10^{6}$, or $10^{9} \mathrm{CFU} / \mathrm{ml}$. The subcutaneous challenges were done by using $0.2-\mathrm{ml}$ portions of suspensions containing $10^{9} \mathrm{CFU} / \mathrm{ml}$. All of the animals challenged by these techniques were alive after 7 days and survived inoculation without noticeable effects, such as local lesions, general abcesses, or microscopic changes. The four positive control mice, which were challenged with Staphylococcus aureus or Escherichia coli, died within $18 \mathrm{~h}$ after injection, whereas the negative control mice injected with PBS alone survived without noticeable trauma.

Autopsies revealed that at challenge levels of $10^{9} \mathrm{CFU} / \mathrm{ml}$ four strains (IFAM NQ-521gr, IFAM MEV-533gr, IFAM I-551, and IFAM KB677) of the Hyphomicrobium group and " $\mathrm{Hy}$ phomonas polymorpha" IFAM PR-727 induced enlargement of the spleens of mice. Strains IFAM 1128 and MEV-533gr caused slight enlargement and a mottled appearance of the kidney cortex. Strains of the genera Prosthecomicrobium, "Stella," Rhodomicrobium, Pedomicrobium, Blastobacter, Planctomyces, and Pasteuria, as well as the negative controls, did not cause any organ changes.

When mice were challenged with those strains that caused enlargement of the kidney cortex or spleen or both and subsequently sacrificed at a rate of one per week, no changes in the enlarged organs were observed for several weeks. Only with strain IFAM 1128 was there a slight reduction in spleen enlargement after 8 weeks.

Spleens, livers, or kidneys of mice infected with those strains which caused enlargement were examined for possible pathological changes. In addition, organs of apparently healthy mice which had been injected with other strains were also studied. Sections stained with periodic acid-Schiff reagent and hematoxylin or with hematoxylin and eosin showed no significant pathological changes, except perhaps a slight enlargement of spleen follicles and a dissemination of the spleenic white pulp. Such changes were not seen in the PBS-treated control animals.

Survival of test bacteria in mice. Most bacteria could not be reisolated after 21 days from the spleens, livers, kidneys, or blood of the mice. Therefore, the survival times of those bacteria which caused spleen changes were tested by intravenous injection of $0.5-\mathrm{ml}$ suspensions containing $10^{9} \mathrm{CFU} / \mathrm{ml}$. Blood samples were taken daily for 10 days and streaked onto the appropriate agar media. Strain IFAM 1128 could not be reisolated after the first day, whereas Hyphomicrobium spp. strains IFAM NQ-521gr and IFAM KB-677 were still recovered after 2 days. Strains IFAM MEV-533gr and IFAM I-551 survived up to 4 days but with aberrant morphology.

In contrast to the other test strains, Rhodomicrobium vaniellii IFAM 1093 and IFAM $1178^{\mathrm{T}}$ survived for 10 days; these strains were readily reisolated from liver or spleen homogenates and were not aberrant (Fig. 1). Therefore, these two strains were injected $\left(0.1 \mathrm{ml} ; 5 \times 10^{8} \mathrm{CFU} / \mathrm{ml}\right)$ into clamped skin folds on mouse backs in an attempt to create more anaerobic conditions. However, neither local lesions nor abcesses developed, and there were no distinct organ changes in these animals. Blood samples con- 


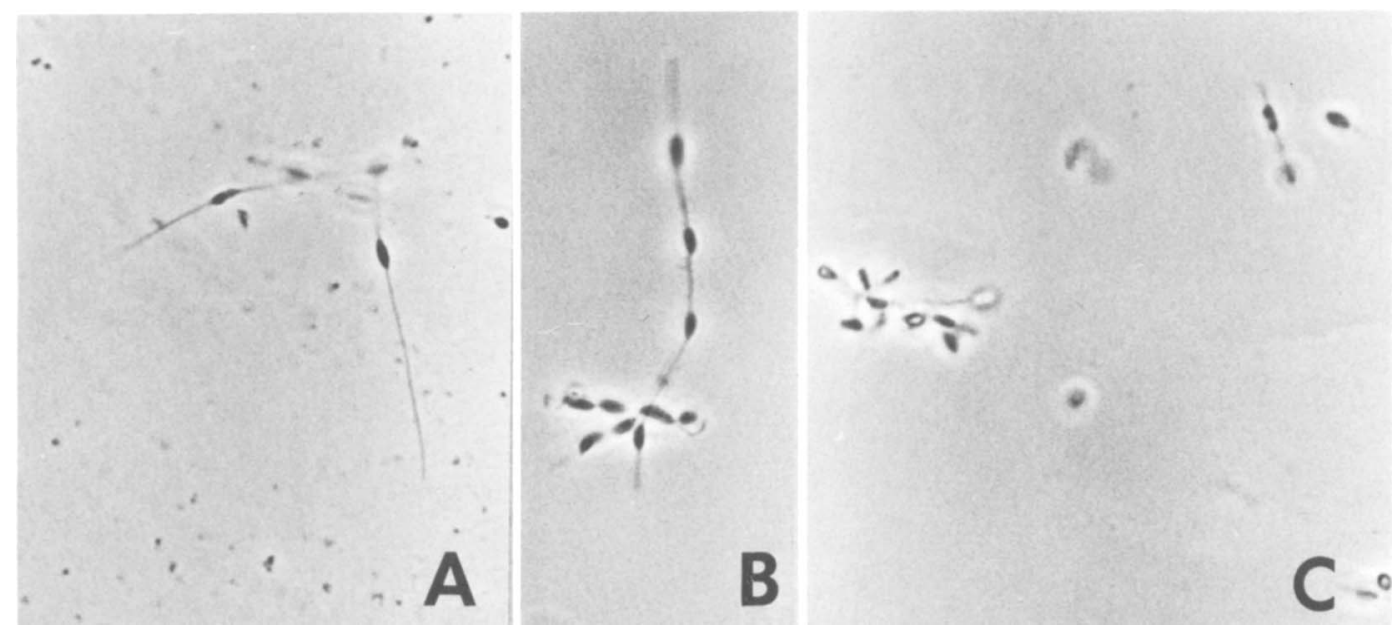

FIG. 1. Rhodomicrobia reisolated after 10 days from mouse organs. $\times 1,080$. (A) $R$. vannielii strain IFAM $1178^{\mathrm{T}}$ reisolated from a liver suspension. (B) $R$. vannielii strain IFAM $1178^{\mathrm{T}}$ reisolated from a spleen suspension. (C) $R$. vaniellii strain IFAM 1093 reisolated from a spleen suspension.

tained Rhodomicrobium-like structures, but these were about 10 times larger than the normal bacteria; these structures were not identified. Thus, it appears that the photosynthetic rhodomicrobia had a greater survival capacity in the hosts than the other bacteria tested.

Toxicity of sonicated cell suspensions. To determine the toxicity of disrupted cells, suspensions of strains IFAM NQ-521gr, IFAM MEV-533gr, IFAM I-551, IFAM KB-677, and IFAM 1128 were sonicated for $3 \mathrm{~min}$, and $0.5 \mathrm{ml}$ of each suspension was injected intravenously into an animal. Although cell breakage was not complete, the cells did not remain viable. None of the test strains had the lethal endotoxic activity of Escherichia coli.

Antigenic properties of the budding and prosthecate bacteria. The serological agglutination reactions carried out on rocked slides showed qualitatively that all infected mice responded to antigens of the test bacteria. More quantitative tests in macrotiter plates showed considerable variation in the agglutination titers; approximately one-half of the strains agglutinated at dilutions of $1: 32$ or $1: 64$. There was no correlation of titer with taxonomic position (Table 2).

Serological cross-reactions were studied by using mouse antisera and six bacterial strains,

TABLE 2. Agglutination reactions of bacterial strains with their homologous antisera

\begin{tabular}{llc}
\hline \multicolumn{1}{c}{ Strain(s) } & \multicolumn{1}{c}{$\begin{array}{c}\text { Genus (known or } \\
\text { suspected) }\end{array}$} & $\begin{array}{c}\text { Highest dilution } \\
\text { causing agglutination }\end{array}$ \\
\hline IFAM 868, IFAM 869 & Pedomicrobium & $1: 2$ \\
IFAM 1093 & Rhodomicrobium & $1: 2$ \\
IFAM ZV-622 & Hyphomicrobium & $1: 4$ \\
IFAM 1003 & Blastobacter & $1: 4$ \\
IFAM 1009 & Pasteuria & $1: 4$ \\
IFAM 1312 "Stella" & $1: 4$ \\
IFAM NQ-521gr, IFAM KB-677 & Hyphomicrobium & $1: 8$ \\
IFAM PS-728 & "Hyphomonas" & $1: 8$ \\
IFAM 1005 & Blastobacter & $1: 8$ \\
IFAM H-526, IFAM CO-582 & Hyphomicrobium & $1: 16$ \\
IFAM 1178T & Rhodomicrobium & $1: 16$ \\
IFAM B-522, IFAM MEV-533gr, IFAM I-551 & Hyphomicrobium & $1: 32$ \\
IFAM ZV-580, IFAM MC-748, IFAM WI-926 & Hyphomicrobium & $1: 32$ \\
IFAM PR-727, IFAM 1325, IFAM LE-670 & "Hyphomonas" & $1: 32$ \\
IFAM 1316 & Prosthecomicrobium & $1: 32$ \\
IFAM 1007 & Planctomyces & $1: 32$ \\
IFAM 1128 & Unknown & $1: 32$ \\
IFAM MC-750 & Hyphomicrobium & $1: 64$ \\
\hline
\end{tabular}


TABLE 3. Serological comparisons of several Hyphomicrobium strains isolated from soil and water

\begin{tabular}{|c|c|c|c|c|c|c|c|c|}
\hline \multirow[b]{2}{*}{ Taxon } & \multirow[b]{2}{*}{ Strain } & \multirow[b]{2}{*}{ Origin } & \multicolumn{6}{|c|}{ Cross-reaction with antiserum against strain: ${ }^{a}$} \\
\hline & & & $\begin{array}{l}\text { IFAM } \\
\text { B-522 }\end{array}$ & $\begin{array}{l}\text { IFAM } \\
\text { I-551 }\end{array}$ & $\begin{array}{l}\text { IFAM } \\
\text { NQ-521gr }\end{array}$ & $\begin{array}{c}\text { IFAM } \\
\text { MEV-533gr }\end{array}$ & $\begin{array}{l}\text { IFAM } \\
\text { KB-677 }\end{array}$ & $\begin{array}{c}\text { IFAM } \\
1128\end{array}$ \\
\hline \multirow{5}{*}{$\begin{array}{l}\text { Hyphomicrobium } \\
\text { spp. }\end{array}$} & IFAM B-522 & Soil & + & + & - & - & - & - \\
\hline & IFAM I-551 & Soil & + & + & - & - & - & - \\
\hline & $\begin{array}{l}\text { IFAM NQ- } \\
521 \mathrm{gr}\end{array}$ & Water & - & - & + & + & + & - \\
\hline & $\begin{array}{l}\text { IFAM MEV- } \\
533 \mathrm{gr}\end{array}$ & Water & - & - & + & + & + & - \\
\hline & IFAM KB-677 & Sewage & - & - & + & + & + & - \\
\hline Unknown & IFAM 1128 & Water & - & - & - & - & - & + \\
\hline
\end{tabular}

$a+$, Positive cross-reaction (agglutination of cells); - , negative cross-reaction.

five of which caused enlargement of spleens (Hyphomicrobium spp. strains IFAM NQ-521gr, IFAM MEV-533gr, IFAM I-551, and IFAM KB677 and unnamed strain IFAM 1128). The sixth strain, Hyphomicrobium sp. strain IFAM B-522, has been widely used in studies of the genus Hyphomicrobium (9, 14-16, 24, 27). Hyphomicrobium spp. strains IFAM B-522 and IFAM I551 , which were isolated from soil and grew without pellicles, did cross-react with one another but not with any of the other three hyphomicrobia, which were isolated from brackish water or sewage and formed surface pellicles (Table 3 ). We observed no cross-reaction of strain IFAM 1128 with any of the other strains.

Infectivity after immunosuppressive treatment of the host. Brown female mice belonging to the pathogen-free strain $\mathrm{C} 3 \mathrm{H}\left(\mathrm{H}-2^{\mathrm{k}}\right)$ were treated intravenously with $0.5 \mathrm{ml}$ of a $1.39 \%$ Natulan solution per $\mathrm{kg}$ of mouse. After 4 days, these mice were challenged with suspensions containing $\left(10^{9} \mathrm{CFU} / \mathrm{ml}\right)$ of those strains that induced enlargement of spleens, as described above. All animals, including the PBS-inoculated negative control, tolerated this immunosuppressive drug very well and survived inoculation. We observed neither symptoms of disease nor pathological changes of internal organs; bacteremia did not develop. However, four immunosuppressed mice challenged with the pathogenic strains of Staphylococcus aureus and Escherichia coli died within $8 \mathrm{~h}$ after infection.

Serological tests indicated that antibodies against the bacteria injected were not produced by the Natulan-treated hosts. However, all animals treated with Natulan, including the controls, had rather pale kidneys as a result of anemic reactions.

Biochemical activities as indicators of possible pathogenicity. Virulent bacteria, including Staphylococcus aureus, Streptococcus pyogenes, and Clostridium tetani, have biochemical reactions that can be correlated with pathogenic- ity (36). Therefore, the bacteria that caused enlargement of spleens or changes in kidneys were examined for hemolytic activities by inoculating sheep blood agar plates with young cell cultures. We observed no $\beta$-hemolysis with any strain; only "Hyphomonas polymorpha" strain IFAM PR-727 was $\alpha$-hemolytic. None of the test strains catabolized mannitol.

In vivo pathogenicity tests with guinea pigs. Five guinea pigs were injected intravenously with 1-ml portions of PBS suspensions containing $10^{9} \mathrm{CFU}$ of stains IFAM NQ-521gr, IFAM MEV-533gr IFAM I-551, IFAM KB-677, IFAM PR-727, and IFAM 1128. After 14 days there were no obvious macroscopic symptoms of infection. When necropsied, the animals infected with strains IFAM NQ-521gr, IFAM MEV-533gr, and IFAM 1128 showed enlargement of the regional lymphatic nodes. Strain IFAM NQ$521 \mathrm{gr}$ induced some swelling of the paraaortic lymph nodes. This indicated the presence of effective defense mechanisms in the animal hosts.

Serological reactions carried out in microtiter plates by using antisera obtained from the infected animals showed host responses to the injected bacteria by antibody formation. Living bacteria could not be isolated from guinea pig organs.

\section{DISCUSSION}

Bacteria capable of causing disease can be widely distributed in natural environments and escape detection, as seen from the recent discovery of Legionella spp. (3). It was for this reason that 27 bacteria that are budding or prosthecate or both were tested for possible pathogenicity in the most extensive study to date $(31,32$; R. Gebers, Ph.D. thesis, Universität Kiel, Kiel, Federal Republic of Germany, 1978).

The results obtained with the Hyphomicrobium strains tested are consistent with the ob- 
servation that these organisms are oligotrophic utilizers of $\mathrm{C}-1$ compounds $(13,14)$ and are inhibited in the presence of low concentrations of certain amino acids (N. Matzen, personal communication). Thus, we can assume, at least for these bacteria, that the nutritional environment in the host is inadequate $(10,35)$. In most cases the maximum temperature for growth of the test strains was above $37^{\circ} \mathrm{C}$.

In our studies pathogenicity was tested in different ways. In addition to the tests for the ability to utilize mannitol and the ability to cause $\beta$-hemolysis, we performed in vivo tests in which we used several routes of infection and different bacterial concentrations. Also, tests for serological reactions and infection after suppression of the host immunological defense system were performed. None of these tests indicated pathogenicity. Animals are considered appropriate to indicate the pathogenic potential of bacteria for humans; in our studies guinea pigs were used in addition to mice, since host susceptibility is regarded as specific generic property of animals (38).

The actual cell densities injected were calculated from measurements of optical density at $650 \mathrm{~nm}$, since parallel determinations of viable counts showed that there was a good correlation between the optical density at $650 \mathrm{~nm}$ and the number of CFU per milliliter. However, several of the test strains (Hyphomicrobium, Blastobacter, and Pasteuria strains) tended to clump or even form rosettes, and in these cases the actual numbers injected would have been higher than the numbers obtained from plate counts.

Initially, the concentrations of bacteria injected were varied from $10^{3}$ to $10^{9} \mathrm{CFU} / \mathrm{ml}$. When we found that even the highest cell density did not seem to affect the hosts, experiments were carried out with this concentration.

The bacteria were administered by different routes. Intravenous injection was used to show the degree of pathogenicity (i.e., virulence) and to determine the bacterial doses necessary to cause disease. Subcutaneous injections were made to study local infectivity, and injections into clamped skin folds were made to create an environment in the hosts as anaerobic as possible to suit the normally anaerobic Rhodomicrobium strains. Interestingly enough, Rhodomicrobium strains were the only bacteria that could be reisolated from the animals after 10 days. A possible explanation for this is that the Rhodomicrobium suspensions may have contained cysts, a type of resting and heat-resistant cell with a certain resemblance to spores (12). The rapid disappearance of the other test bacteria from the host bloodstreams could have been caused by (i) nutritional unsuitability of the host environment or (ii) the presence of an effective defense system in the host. Resistance could be related to an active reticuloendothelial system, which is known to cause phagocytosis and destruction of bacteria circulating in the blood. The presence of antibacterial substances in the bloodstream or serum of a host could also account for the inability of the bacteria to survive $(7,28)$.

The in vivo tests with mice and guinea pigs revealed neither virulence nor toxicity in the 27 bacteria. Enlargement of spleens and a mottled appearance of kidneys in the case of some closely related strains were evidently normal host reactions to the presence of the bacteria. A histological examination of the enlarged spleens revealed minor follicular changes and dissemination of the spleenic white pulp, which can be attributed to increased stimulation of cellular defense $(6,33,34)$, to the elimination process of the spleen (5), or to antibody-antigen complex reactions (26).

The agglutination tests with antisera and the corresponding strains showed that all animals responded to the presence of the bacteria by antibody formation. Therefore, serological cross-reactions could be carried out with selected strains to look for antigenic relationships. The few preliminary experiments which we performed indicated that Hyphomicrobium strains obtained from soil cross-reacted, but that these strains did not react with aquatic strains (Table 3 ). This demonstrates the presence in the genus Hyphomicrobium of different taxonomic subgroups, an observation made previously by Mandel et al. (24), Moore and Hirsch (27), and Powell et al. (32).

The non-infectivity of the 27 strains could be demonstrated after immunosuppressive treatment of mice. Natulan, a substance used in transplantation work, affects mainly the humoral response of a host (2), yet the infectious capacities of our test bacteria were not enhanced. Lack of virulence in our strains could have been due to continued culture on laboratory media. To test this, new isolates would have had to be isolated and maintained on media promoting virulence. The low virulence of this group of bacteria was underscored by the inability of 10 strains to utilize mannitol or cause $\beta$-hemolysis (36).

\section{ACKNOWLEDGMENTS}

We acknowledge receipt of bacterial cultures from $W$ Mevius, Jr., G. A. Zavarzin, J. Y. Kingma-Boltjes, E. Leifson, E. Pongratz, W. Babinchak, and F. Eckhardt. We also appreciate the help in the histological parts of this work kindly rendered by our colleagues L. Rath, E. Haase, and H. K. Müller-Hermelink (Universität Kiel).

\section{LITERATURE CITED}

1. Austin, B., D. A. Allen, A. Zachary, M. R. Belas, and R. R. Colwell. 1979. Ecology and taxonomy of bacteria 
attaching to wood surfaces in a tropical harbour. Can. J. Microbiol. 25:447-461.

2. Bach, J. F. 1975. The mode of action of immunosuppressive agents. North-Holland Publishing Co., Amsterdam.

3. Brenner, D. J., A. G. Steigerwalt, and J. E. McDade. 1979. Classification of the Legionnaire's disease bacterium: Legionella pneumophila, genus novum, species nova, of the family Legionellaceae, familia nova. Ann. Intern. Med. 90:656-658.

4. Buchanan, R. E., and N. E. Gibbons (ed.). 1974. Bergey's manual of determinative bacteriology, 8th ed. The Williams \& Wilkins Co., Baltimore.

5. Burnett, F. M. 1962. Natural history of infectious disease. Cambridge University Press, London.

6. Congdon, C. C., and T. Makinodan. 1961. Spleenic white pulp alteration after injection: relation to time of serum antibody production. Am. J. Pathol. 39:697-709.

7. Cybulska, J., and J. Jeljaszewicz. 1966. Bacteriostatic activity of serum against Staphylococcus. J. Bacteriol. 91:953-962.

8. Duchow, E., and H. C. Douglas. 1949. Rhodomicrobium vannielii, a new photoheterotrophic bacterium. J. Bacteriol. 91:409-416.

9. Eckhardt, F., P. Roggentin, and P. Hirsch. 1979. Fatty acid composition of various hyphal budding bacteria. Arch. Microbiol. 120:81-85.

10. Garber, E. D. 1960 . The host as a growth medium. Ann. N.Y. Acad. Sci. 85:1187-1194.

11. Ghiorse, W. C., and P. Hirsch. 1979. An ultrastructural study of iron and manganese deposition associated with extra-cellular polymers of Pedomicrobium-like bacteria. Arch. Microbiol. 123:213-226.

12. Gorlenko, V. M. 1969. Spore formation in a budding photoheterotrophic bacterium. Mikrobiologiya 38:106111.

13. Harder, W., and M. M. Attwood. 1978. Biology, physiology and biochemistry of Hyphomicrobium. Adv. Microb. Physiol. 17:303-359.

14. Hirsch, P. 1974. Budding bacteria. Annu. Rev. Microbiol. 28:391-444.

15. Hirsch, P., and S. F. Conti. 1964. Biology of budding bacteria. I. Enrichment, isolation and morphology of Hyphomicrobium spp. Arch. Mikrobiol. 48:339-357.

16. Hirsch, P., and S. F. Conti. 1964. Biology of budding bacteria. II. Growth and nutrition of Hyphomicrobium spp. Arch. Mikrobiol. 48:358-367.

17. Hirsch, P., M. Müller, and H. Schlesner. 1977. New aquatic budding and prosthecate bacteria and their taxonomic position. Soc. Appl. Bacteriol. Symp. Ser. 6:107133.

18. Hirsch, P., and G. Rheinheimer. 1968. Biology of budding bacteria. V. Budding bacteria in aquatic habitats: occurrence, enrichment and isolation. Arch. Mikrobiol. 62:289_ 306.

19. Hurlbert, E., J. Weckesser, H. Mayer, and I. Fromme. 1976. Isolation and characterization of the lipopolysaccharide of Chromatium vinosum. Eur. J. Biochem. 68:365-371.

20. Katz, A., J. Weckesser, and G. Drews. 1977. Chemical and biochemical studies on the lipopolysaccharide (O-antigen) of Anacystis nidulans. Arch. Microbiol. 113:247-256.
21. Kingma-Boltjes, J. Y. 1936. Über Hyphomicrobium vulgare Stutzer \& Hartleb. Arch. Mikrobiol. 7:188-205.

22. Leifson, E. 1964. Hyphomicrobium neptunium sp.n. Antonie van Leeuwenhoek J. Microbiol. Serol. 30:249-256.

23. Lyman, J., and R. H. Fleming. 1940. Composition of seawater. J. Mar. Res. 3:134-146.

24. Mandel, M., P. Hirsch, and S. F. Conti. 1972. Deoxyribonucleic acid base compositions of hyphomicrobia. Arch. Mikrobiol. 81:289-294.

25. Mevius, W., Jr. 1953. Beiträge zur Kenntnis von Hyphomicrobium vulgare Stutzer \& Hartleb. Arch. Mikrobiol. 19:1-29.

26. Miescher, P. A., and H. J. Müller-Eberhard. 1968. Textbook of immunopathology, vol. 1. Grune \& Stratton, New York.

27. Moore, R. L., and P. Hirsch. 1972. DNA base sequence homologies of some budding and prosthecate bacteria. $\mathbf{J}$. Bacteriol. 110:256-261.

28. Muschel, L. H. 1960. Serum bactericidal action. Ann. N. Y. Acad. Sci. 88:1265-1272.

29. Pfennig, N. 1969. Rhodopseudomonas acidophila sp.n., a new species of the budding purple nonsulfur bacteria. J. Bacteriol. 99:597-602.

30. Pfennig, N., and K. D. Lippert. 1966. Über das Vitamin $\mathrm{B}_{12}$-Bedürfnis phototropher Schwefelbakterien. Arch. Mikrobiol. 55:258-266.

31. Pongratz, E. 1957. D'une bactérie pédiculée isolée d'un pus de sinus. Schweiz. Z. Pathol. Bakteriol. 20:593-608.

32. Powell, D. M., B. S. Roberson, and R. M. Weiner. 1980 Serological relationships among budding, prosthecate bacteria. Can. J. Microbiol. 26:209-217.

33. Robbins, S. L. 1974. Pathologic basis of disease. Saunders Co., Philadelphia.

34. Roitt, I. 1977. Essential immunology, 3rd ed. Blackwel Scientific Publications, London.

35. Smith, H. 1976. Survival of vegetative bacteria in animals. Symp. Soc. Gen. Microbiol. 26:299-326.

36. Sonntag, H. G., and K. Nachtigall. 1977. Vergleichende Untersuchungen über biochemische Pathogenitätsmerkmale und Resistenzverhalten gegen Antibiotika bei Staphylokokken. Zentralbl. Bakteriol. Parasitenkd. Infektionskr. Hyg. Abt. 1 Orig. Reihe A 238:310-319.

37. Staley, J. T. 1968. Prosthecomicrobium and Ancalomicrobium: new prosthecate freshwater bacteria. J Bacteriol. 95:1921-1942.

38. Strong, L. C. 1978. Origins of inbred mice. Academic Press, Inc., New York.

39. Van Ert, M., and J. T. Staley. 1971. Gas-vacuolated strains of Microcyclus aquaticus. J. Bacteriol. 108:236240.

40. Vasil'eva, L. V. 1970. A star-shaped soil microorganism. Izv. Akad. Nauk SSSR Ser. Biol. 2:308-310.

41. Weckesser, J., G. Drews, and H. Mayer. 1977. Lipopolysaccharide aus Zellwänder. photosynthetischer Prokaryonten: Bedeutung für Fragen der Taxonomie und der endotoxischen Aktivität. Naturwiss. Rundsch. 30:360 364.

42. Zavarzin, G. A. 1960 . The life-cycle and nuclear apparatus in Hyphomicrobium vulgare Stutzer and Hartleb. Mikrobiologiya 29:24-27. 